\title{
KEWENANGAN PENGADILAN NIAGA MENGADILI PERKARA KEPAILITAN TERHADAP ADANYA KLAUSULA ARBITRASE DALAM PERJANJIAN YANG DISEPAKATI
}

\author{
Didin R Dinovan \\ Universitas Azzahra, Jakarta \\ dinovanlaw@ymail.com
}

\begin{abstract}
ABSTRAK
Penelitian ini bertujuan untuk mengetahui sampai sejauh mana Kewenangan Pengadilan Niaga Mengadili Perkara Kepailitan Terhadap Adanya Klausula Arbitrase Dalam Perjanjian Yang Disepakati. Penelitian dilakukan bertujuan untuk mengetahui kewenangan luar biasa (extra ordinary power) yang dimiliki oleh Pengadilan Niaga melalui Pasal 300 ayat (1) Undang-Undang No. 37 tahun 37 jo. Pasal 280 ayat (1) Undang-Undang No. 4 tahun 1998 tentang Kepailitan dan Penundaan Kewajiban Pembayaran Utang versus kewenangan khusus (extra judicial power) yang dimiliki oleh Lembaga Arbitrase berdasarkan Pasal 615-651 RV dan Pasal 11 Undang-Undang No. 30 tahun 1999 tentang Arbitrase. Penelitian dilakukan melalui studi lapangan dan studi kepustakaan. Responden penelitian terdiri dari para Hakim Pengadilan Niaga dan para Advokat yang pernah menanganinya. Dari analisis data hasil penelitian dapat disimpulkan bahwa, Pertama Perkara Permohonan Kepailitan yang dasarnya dari perjanjian berklausula arbitrase dapat diperiksa, diadili dan diputuskan oleh Pengadilan Niaga, karena Pengadilan Niaga mempunyai kewenangan/ kompetensi absolut sesuai dengan ketentuan Pasal 300 Undang-Undang No. 37 tahun 2004 jo. Pasal 1 jo. 280 ayat (1) UndangUndang No. 4 tahun 1998. Kedua Permohonan Kepailitan yang dasarnya dari perjanjian berklausula arbitrase dapat langsung diajukan ke Pengadilan Niaga tanpa harus terlebih dahulu ada proses penyelesaian di Lembaga arbitrase, sebagaimana ditentukan dalam Pasal 303 Undang-Undang No.37 tahun 2004 tentang Kepailitan dan Penundaan Kewajiban Pembayaran Utang.
\end{abstract}

Kata kunci: Kewenangan Pengadilan Niaga, Berklausula Arbitrase, Perkara Kepailitan, Upaya Hukum.

\begin{abstract}
The aim of the research to know how far the Jurisdiction of Commercial Court judge on Bankruptcy Case to related to the Arbitration Clausal in Agreement that has been Agreed. The aim of the research to know the extra ordinary power that had by the Commercial Court as on article 300 clause (1) Act No. 37, 1937 jo. Article 280 clause (1) Act No 4, 1998 about Bankruptcy and Postponement of Debt Payment Obligation versus extra judicial power that had by Arbitration Institution based on Article 615-651 RV and Article 11 Act No. 30, 1999 about Arbitration. The Research conducted through field study and bibliography study. Respondent of the research consist of Judges of Commercial Court and Lawyers handling the matters. From data analysis the conclusion of this research are, First, The application of Bankruptcy Case which basically came from agreement with in arbitration clause can be checked, judged and decided by the Commercial Court, because Commercial Court have an absolute jurisdiction as mentioned in article 300 Act No. 37, 2004 jo. Article 1 jo. 280 clause (1) Act No. 4, 1998. Second, Application of Bankruptcy which basically came from agreement which in arbitration clausal can be directly submitted to Commercial Court without having settlement process in
\end{abstract}

Didin R Dinovan, Kewenangan Pengadilan Niaga Mengadili Perkara Kepailitan ..... 
Arbitration Institution as determined in Article 303 Act No. 37, 2004 about Bankruptcy and Postponement of Debt Payment Obligation.

Keywords: Jurisdiction of Commercial Court, Arbitration clausal, Bankruptcy Case, LegalRemed.

\section{PENDAHULUAN}

Tanggal 22 April 1998 pemerintah menetapkan Peraturan Pemerintah Pengganti Undang-Undang (Perpu) No. 1 tahun 1998 tentang Perubahan atas UndangUndang Kepailitan guna menyempurnakan ketentuan kepailitan sebagaimana diatur dalam Failissement Verordening Staatsblad No. 217 tahun 1905 jo Staatsblad No. 384 tahun 1906, sebagai bagian dari usaha pemerintah untuk meningkatkan kembali kepercayaan investor asing terhadap jaminan penanaman modalnya di Indonesia dan memberikan dasar hukum yang tepat dalam upaya menyelesaikan permasalahan utangpiutang. Perpu tersebut disahkan sebagai Undang-Undang No. 4 Tahun 1998 tentang Kepailitan (UUK) pada tanggal 24 Juli 1998. Sejalan tuntutan perkembangan masyarakat, ketentuan tersebut dirasa belum mampu memenuhi kebutuhan hukum masyarakat, sehingga perlu dilakukan perubahan yang ditetapkan pada tanggal 18 Oktober 2004 melalui Undang-Undang No. 37 tahun 2004 tentang Kepailitan dan Penundaan Kewajiban Pembayaran hutang.

Pengadilan Niaga adalah pengadilan khusus yang mengadili perkara kepailitan dan PKPU, maka setiap penyelesaian sengketa niaga seperti pembuktian dan verifikasi utang, actio pauliana, hingga pemberesan harta pailit, menjadi kewenangan absolut Pengadilan Niaga, selain memiliki kewenangan absolut terhadap setiap perkara kepailitan sebagai pelaksanaan dari Perpu No. 1 tahun 1998. Pengadilan Niaga juga memiliki kompetensi untuk menyelesaikan beberapa sengketa di bidang perdagangan, terutama Hak atas Kekayaan Intelektual (HaKI).

Dalam hubungan dagang yang dilandasi dengan perjanjian, tidak tertutup pula adanya kemungkinan para pihak memilih penyelesaian sengketa dagang, termasuk pula penyelesaian perselisihan utang-piutang melalui Lembaga Arbitrase, pelaku bisnis biasanya lebih memilih penyelesaian sengketa secara Arbitrase yang dituangkan ke dalam perjanjian dalam meilih penyelesaian jika terjadi perselisihan.Undang-Undang Nomor 30 Tahun 1999 tentang Arbitrase dan Alternatif Penyelesaian Sengketa mengatur tentang beberapa pola penyelesaian sengketa di luar pengadilan. Pola penyelesaian tersebut, antara lain : konsultasi, negosiasi, mediasi, konsiliasi, penilaian ahli (expert), dan arbitrase (perwasitan). Syarat mutlak untuk bisa membawa penyelesaian perkara dengan pola tersebut, berdasarkan pasal 2 Undang-Undang Arbitrase, diharuskan adanya perjanjian yang berklausula Arbitrase. Perjanjian tersebut dapat dibuat sebelum maupun sesudah timbulnya sengketa.

Konsekuensi hukum dari dibuatnya perjanjian aribitrase berdasarkan pasal 3 Undang-Undang Arbitrase, adalah dalam hal timbul sengketa sebagai akibat dari pelanggaran perjanjian tersebut, Pengadilan Negeri tidak berwenang untuk mengadilinya. Apabila salah satu pihak berusaha mengajukan sengketa tersebut ke lembaga peradilan, maka berdasarkan pasal 11 ayat 2 Undang-Undang Arbitrase, Pengadilan Negeri wajib menolak dan tidak akan campur tangan dalam suatu sengketa yang telah ditetapkan melalui arbitrase. Beberapa kelebihan dari pola penyelesaian di luar pengadilan antara lain : terjaminnya kerahasiaan (confidentiality) para pihak

Didin R Dinovan, Kewenangan Pengadilan Niaga Mengadili Perkara Kepailitan ..... 
karena forumnya tertutup untuk umum, relatif lebih cepat karena adanya batas waktu yang ketat, prosedurnya tidak berbelit-belit, serta para pihak diberi kebebasan untuk memilih arbiter (wasit) mediator, konsiliator, atau negosiator yang mereka nilai ahli (qualified), jujur, dan adil.

Para pihak yang bersengketa boleh memilih hukum yang berlaku untuk menyelesaikan substansi sengketa mereka (choise of law), dan putusan (vonnis) yang dibuat secara non litigasi bersifat final dan mengikat (final and binding), artinya tidak boleh ada upaya hukum banding, kasasi atau peninjauan kembali (PK). Kontraversi terhadap kewenangan khusus yang dimiliki oleh kedua lembaga Arbitrase dan Pengadilan Niaga dari para pemerhati hukum dan praktisi hukum, Hakim, Konsultan Hukum, maupun kalangan akademisi, sampai dengan saat ini masih terdapat pro dan kontra, apakah klausula Arbitrase dapat mengesampingkan kewenangan khusus dari Pengadilan Niaga untuk memeriksa dan memutuskan permohonan pernyataan pailit ataupun permohonan Penundaan Kewajiban Pembayaran Utang (PKPU).

\section{Rumusan Masalah}

Dalam penelitian ini, penulis membagi permasalahan sebagai berikut :

1. Apakah kewenangan luar biasa (extra ordinary power) yang dimiliki oleh Pengadilan Niaga melalui Pasal 280 ayat (1) Undang-Undang No.1 Tahun 1998 jo. Pasal 300 ayat (1) Undang-Undang No.37 Tahun 2004 Tentang Kepailitan dan Penundaan Kewajiban Pembayaran Utang, dapat mengadili kewenangan khusus (extra judicial power) yang dimiliki oleh Arbitrase berdasarkan Pasal 615-651 RV dan Pasal 11 Undang-Undang No.30 Tahun 1999 Tentang Arbitrase?

2. Bagaimana kekuatan pelaksanaan keputusan Pengadilan Niaga terkait dengan perkara kepailitan yang terdapat klausula Arbitrase dalam perjanjian yang telah disepakati ?

3. Adakah upaya hukum bagi pihak yang dirugikan karena dijatuhkan pailit, terkait dengan ketentuan Arbitrase yang sudah disepakati dalam perjanjian, yang menunjuk Lembaga Arbitrase dalam penyelesaian permasalahan yang di hadapi para pihak?

\section{Tujuan Penelitian}

Penelitian ini secara umum bertujuan untuk menambah masukan di bidang ilmu hukum, khususnya dalam bidang hukum Kepailitan dan Alternatif Penyelesaian melalui lembaga arbitrase. Selain itu, tujuan khusus yang ingin dicapai dari penelitian ini adalah untuk mengetahui aspek hukum penyelesaian perkara utang piutang, dimana dalam surat perjanjian yang disepakati para pihak telah dicantumkan adanya klausula Arbitrase dalam penyelesaian masalah jika terjadi sengketa, bagaimana kalau penyelesaian sengketa yang notabene sudah merujuk kepada Arbitrase akan tetapi peneyelesiannya memilih melalui prosedur hukum gugatan kepailitan kepada Pengadilan Niaga.

Didin R Dinovan, Kewenangan Pengadilan Niaga Mengadili Perkara Kepailitan ..... 


\section{HASIL PENELITIAN DAN PEMBAHASAN}

\section{Kewenangan Absolut Pengadilan Niaga}

Untuk mempertegas kompetensi/kewenangan absolut Pengadilan Niaga terhadap perkara kepailitan, sesuai dengan Pasal 280 ayat (1) Perpu No. 1 tahun 1998 yang telah ditetapkan menjadi Undang-undang No. 4 tahun 1998 kemudian diubah menjadi Undang-Undang No.37 Tahun 2004 Tentang Kepailitan Dan Penundaan Kewajiban Pembayaran Utang. Telah meletakkan Pengadilan Niaga sebagai bagian yang tidak terpisahkan dalam struktur Pengadilan Negeri dengan kewenangan khusus berupa yurisdiksi substansif eksklusif terhadap penyelesaian perkara kepailitan. Dengan status hukum dan kewenangan (legal status and power), Pengadilan Niaga memiliki kapasitas hukum (legal capacity) untuk menyelesaikan permohonan pailit.

Kompetensi pengadilan menurut ketentuan undang-undang mengenal ada dua macam kompetensi suatu lembaga peradilan, yaitu kompetensi relative dan kompetentsi absolute. Kompetensi relative menunjuk pada kewenangan mengadili suatu lembaga peradilan berdasarkan wilayah yurisdiksi tempat pengadilan itu berada. Kompetensi absolute merupakan kewenangan mengadili suatu lembaga berdasarkan pokok perkaranya.

Pengadilan Niaga memiliki kewenangan absolut dalam kedudukannya sebagai extra ordinary court yang diberikan melalui amanat Perpu No. 1 tahun 1998 jo Undang-undang No. 4 tahun 1998 jo. Undang-Undang No.37 Tahun 2004 Tentang Kepailitan dan Penundaan Kewajiban Pembayaran Utang sebagai special law untuk mengadili dan menyelesaikan permohonan pailit dan insolvensi. Yurisdiksi substansif eksklusif tersebut mengangkat dan mengesampingkan kewenangan absolut dari Arbitrase sebagai pelaksanaan prinsip pacta sunt servanda yang digariskan dalam Pasal 1338 Kitab Undang-undang Hukum Perdata yang telah memberikan pengakuan extra judicial atas klausula Arbitrase untuk menyelesaikan sengketa para pihak sebagaimana telah diperjanjikan.

Klausula Arbitrase baru dapat memiliki kewenangan absolut untuk mementahkan hak memeriksa dan mengadili apabila berhadapan dengan kewenangan absolut Pengadilan Negeri. Kedudukan tersebut telah ditegaskan dalam Pasal 11 ayat (2) Undang-undang No. 30 tahun 1999 tentang Arbitrase jo Pasal 3 Undang-Undang No. 14 tahun 1970 jo Pasal 377 Herzien Inlandsch Reglement jo Pasal 615-651 Reglement op de Rechtsvordering.

Berdasarkan ketentuan dalam Pasal 280 ayat (1) Undang-Undang No. 4 tahun 1998 jo. Pasal 300 Undang-Undang No.37 tahun 2004 telah dengan tegas diatur bahwa tentang kewenangan Pengadilan Niaga untuk memeriksa dan memutuskan permohonan pailit ataupun PKPU, sebagai berikut: "Permohonan pernyataan pailit dan Penundaan Kewajiban Pembayaran Utang sebagaimana dimaksud dalam bab pertama dan bab kedua, diperiksa dan diputuskan oleh Pengadilan Niaga yang berada di lingkungan Peradilan Umum". Selanjutnya dalam penjelasan Pasal 280 ayat (1) ditegaskan sebagai berikut: "Dengan ketentuan ini semua permohonan pernyataan pailit dan Penundaan Kewajiban Pembayaran Utang yang diajukan setelah berlakunya Undang-undang tentang kepailitan sebagaimana

Didin R Dinovan, Kewenangan Pengadilan Niaga Mengadili Perkara Kepailitan ..... 
diubah dengan Peraturan Pemerintah Pengganti Undang-undang ini hanya dapat diajukan kepada Pengadilan Niaga". Ketentuan Pasal 280 ayat (1) beserta dengan penjelasannya tersebut memang dengan tegas telah memberikan kewenangan khusus kepada Pengadilan Niaga sebagai satu-satunya pengadilan yang berwenang untuk memeriksa dan memutuskan permohonan kepailitan dan PKPU.

\section{Kewenangan Khusus Lembaga Arbitrase Sebagai Alternatif Penyelesaian Sengketa Bisnis.}

Undang-Undang No.30 tahun 1999 tentang Arbitrase (UU Arbitrase), pasal 1 ayat (1): menyebutkan "Arbitrase merupakan cara penyelesaian suatu sengketa perdata diluar peradilan umum yang didasarkan pada perjanjian arbitrase yang dibuat secara tertulis oleh para pihak yang bersengketa". Sebelum UU Arbitrase berlaku, ketentuan mengenai arbitrase diatur dalam pasal 615 s/d 651 Reglemen Acara Perdata (Rv). Selain itu, pada penjelasanpasal 3 ayat(1) Undang-Undang No.14 Tahun 1970 tentang Pokok-Pokok Kekuasaan Kehakiman menyebutkan bahwa penyelesaian perkara di luar Pengadilan atas dasar perdamaian atau melalui wasit (arbitrase) tetap diperbolehkan.

Klausula arbitrase adalah nyawa dari arbitrase. Klausula arbitrase akan menentukan apakah suatu sengketa bisa diselesaikan melalui arbitrase, dimana diselesaikannya, hukum mana yang digunakan, dan lain-lain. Klausula arbitrase bisa berdiri sendiri atau terpisah dari perjanjian pokonya. Tidak ada keharusan dalam undang-undang Arbitrase yang menentukan klausula arbitrase yang dibuat dalam akta notaris. Klausula arbitrase harus disusun secara cermat, akurat, dan mengikat.

Tujuannya untuk menghindari klausula arbitrase tersebut digunakan oleh salah satu pihak sebagai kelemahan yang bisa digunakan untuk memindahkan sengketa tersebut ke jalur pengadilan. BANI (Badan Arbitrase Nasional Indonesia), dengan memuat klausula arbitrase sebagai berikut: "Semua sengketa yang timbul dari perjanjian ini, akan diselesaikan dan diputus oleh Badan Arbitrase Nasional Indonesia (BANI) menurut peraturan-peraturan prosedur arbitrase BANI, yang keputusannya mengikat kedua belah pihak yang bersengketa, sebagai keputusan dalam tingkat pertama dan terakhir". Standar klausula arbitrase UNCITRAL (United Nation Comission of International Trade Law) adalah sebagai berikut: "Setiap sengketa, pertentangan atau tuntutan yang terjadi atau sehubungan dengan perjanjian ini, atau wanprestasi, pengakhiran atau sah tidaknya perjanjian akan diselesaikan melalui arbitrase sesuai dengan aturan-aturan UNCITRAL. Menurut Priyatna Abdurrasyid, Ketua BANI, yang diperiksa pertama kali adalah klausula arbitrase. Artinya ada atau tidaknya, sah atau tidaknya klausula arbitrase, akan menentukan apakah suatu sengketa akan diselesaikan lewat jalur arbitrase, dan bisa saja klausula atau perjanjian arbitrase dibuat setelah sengketa timbul.

\section{Sengketa Kewenangan Mengadili Antara Arbitrase Dan Pengadilan Niaga.}

Sengketa kewenangan mengadili antara Arbitrase dan Pengadilan Niaga timbul sebagai akibat tindakan salah satu pihak bersengketa telah membuat perjanjian yang

Didin R Dinovan, Kewenangan Pengadilan Niaga Mengadili Perkara Kepailitan ..... 
berklausula arbitrase itu sendiri. Berdasarkan perjanjian arbitrase tertulis yang telah disepakati para pihak, semestinya apabila timbul sengketa mereka mengajukan penyelesaiannya ke Lembaga Arbitrase tidak ke Pengadilan Negeri atau Pengadilan Niaga. Tetapi dengan alasan bahwa sengketa perdata mereka adalah sengketa kepailitan, maka salah satu diantara mereka mengajukan penyelesaiannya ke Pengadilan Niaga. Sehingga timbullah sengketa kewenangan mengadili antara Arbitrase dan Pengadilan Niaga.

Pasal 3 Undang-Undang No.30/1999 menentukan bahwa Pengadilan Negeri tidak berwenang untuk mengadili sengketa para pihak yang telah terikat dengan perjanjian arbitrase. Demikian pun Pasal 11 ayat (2) Undang-Undang No.30/1999 mengatur bahwa Pengadilan Negeri wajib menolak dan tidak ikut campur tangan di dalam suatu sengketa yang telah ditetapkan dalam undang-undang ini. Dengan demikian status hukum (legal status) dan kapasitas hukum (legal capacity) Pengadilan Niaga yang berkarakter extra ordinary court yang khusus menyelesaikan permohonan pailit, tidak dapat disingkirkan kewenangannya oleh arbitrase dalam kedudukan dan kapasitas hukumnya sebagai extra judicial. Terhadap sengketa perdata dengan perjanjian arbitrase serupa, Mahkamah Agung telah menjatuhkan putusan yang sama dengan menyatakan bahwa klausula arbitrase dalam perjanjian tidak dapat mengesampingkan kewenangan Pengadilan Niaga untuk memeriksa dan memutus perkara permohonan pernyataan pailit.

Berdasarkan ketentuan Pasal 280 Peraturan Pemerintahan Pengganti UndangUndang dengan Undang-Undang No.1 Tahun 1998 yang telah ditetapkan menjadi Undang-Undang No.4 Tahun 1998 kemudian diganti dengan Undang-Undang No.37 tahun 2004, Pengadilan Niaga berwenang memeriksa dan memutus perkara permohonan pernyataan pailit. Apabila Pengadilan Niaga mendasarkan ketentuan Pasal 8 ayat (4) UU Kepailitan, menolak permohonan pernyataan pailit yang diajukan oleh kreditor yang telah membuat perjanjian arbitrase dengan debitor. Apakah akibat hukumnya terhadap perjanjian arbitrase? Jika, Pengadilan Niaga menolak permohonan pernyataan pailit yang diajukan oleh kreditor yang membuat perjanjian arbitrase berdasarkan azas pactum de compromittendo maupun azas kompromis, maka lembaga arbitrase kembali hidup untuk menyelesaikan sengketa perdata antara kreditor dan debitor. Sebaliknya, apabila Pengadilan Niaga ternyata mengabulkan permohonan pernyataan pailit dengan alasan bahwa perjanjian arbitrase terbukti secara sederhana, maka kewenangan arbitrase untuk menyelesaikan sengketa paerdata antara kreditor dan debitor yang telah membuat perjanjian arbitrase yang dibuat sebelum ada sengketa arbitrase (pactum de compromittendo) maupun dibuat setelah adanya sengketa arbitrase (akta kompromis), maka menjadi tidak lagi mempunyai kewenangan yang khusus secara absolut.

Hal ini telah dengan tegas diatur dalam Undang-Undang No.37 tahun 2004 tentang Kepailitan dan Penundaan Kewajiban Pembayaran Utang, dimana dalam ketentuan : Pasal 31 ayat (1) dengan tegas menyatakan : "Putusan pernyataan pailit berakibat bahwa segala penetapan pelaksanaan pengadilan terhadap setiap bagian dari kekayaan Debitur yang telah dimulai sebelum keapilitan, harus dihentikan seketika dan sejak itu tidak ada suatu putusan yang dapat dilaksanakan termasuk atau

Didin R Dinovan, Kewenangan Pengadilan Niaga Mengadili Perkara Kepailitan ..... 
juga dengan menyandera Debitur", seperti yang dimaksud dalam Pasal 1 ayat (3) UU No.30 Tahun 1999 mengenai arti perjanjian arbitrase, maka perjanjian arbitrase bisa dibuat sebelum ada sengketa atau sesudah ada sengketa, pertama perjanjian arbitrase sebelum ada pernyataan pailit, kedua perjanjian arbitrase pada saat proses kepailitan berjalan dan yang ketiga adalah perjanjian arbitrase setelah ada putusan pernyataan pailit.

Apabila belum ada suatu perkara yang diajukan ke Pengadilan Niaga dengan alasan permohonan pernyataan pailit, debitor dan kreditor yang membuat perjanjian pailit terdapat sengketa, maka menurut ketentuan Pasal 61 UU No.30 Tahun 1999 sengketa tersebut harus diajukan para pihak ke lembaga arbitrase. Jadi, apabila ada sengketa perdata yang disertai perjanjian arbitrase tertulis tapi belum ada proses perkara permohonan pernyataan pailit di Pengadilan Niaga maka sesuai dengan ketentuan Pasal 61 UU No.30/1999, para pihak yang bersengketa tadi menyelesaikan persoalannya melalui lembaga arbitrase. Lembaga arbitrase menyelesaikan sengketa diantara kreditor dan debitor yang telah membuat perjanjian arbitrase, yang dilaksanakan atas dasar perjanjian yang dibuat para pihak yang kemudian akan lahir putusan arbitrase.

Namun bagaimana seandainya ada kreditor lain yang tidak terikat perjanjian arbitrase mengajukan permohonan pernyataan pailit kepada debitor yang terikat perjanjian arbitrase? Kemudian Pengadilan Niaga mengabulkan permohonan pernyataan pailit kreditor lain tadi. Bagaimanakah nasib putusan lembaga arbitrase yang telah diputuskan terhadap kreditor dan debitor yang terikat dalam perjanjian arbitrase tadi? Disini timbul suatu masalah. Solusinya, apabila sedah diputuskan dinyatakan pailit debitor yang terikat perjanjian arbitrase tadi, maka proses penyelesaian utang-piutangnya adalah melalui rapat pencocokan piutang atau disebut dengan rapat verifikasi. Di situlah Kurator atas dasar ketentuan Pasal 16 ayat (1) UU Kepailitan dan Pasal 69 UU Kepailitan bertugas melaksanakan putusan permohonan pernyataan pailit dalam arti pengurusan dan/atau pemberesan harta pailit. Pengurusan dan pemberesan harta pailit ini yang merupakan kewenangan Kurator yang dilaksanakan dalam rapat pencocokan piutang.

Bagaiman nasib kreditor yang mempunyai hak tagih atas dasar putusan arbitrase? Kreditor tersebut juga mempunyai kewajiban menyampaikan tagihannya kepada Kurator. Jadi hak-hak yang dia terima atas dasar putusan arrbitrase disampaikan kepada kurator, kemudian kurator akan mencatat nama-nama kreditor tersebut, jumlahnya dan sifat-sifat dari utangnya, yaitu apabila sebelum permohonan pernyataan pailit dijatuhkan. Pada saat pernyataan pailit bersamaan dengan proses perkara Arbitrase, De Debitor dan kreditor menyelesaikan sengketanya melalui lembaga arbitrase. Kemudian juga ada perkara permohonan pernyataan pailit di Pengadilan Niaga. Apabila terjadi kasus semacam ini, diharapkan lembaga arbitrase untuk sementara menunda dulu tugasnya melaksanakan penyelesaiannya melalui lembaga arbitrase. Karena apabila kemudian Pengadilan Niaga memutuskan mengabulkan permohonan pernyataan pailit kreditor, maka putusan arbitrase tadi tidak akan bisa dilaksanakan oleh Ketua Pengadilan Negeri. Hal ini karena menurut ketentuan Pasal 31 ayat (1) UUK, segala pelaksanaan putusan pengadilan yang terjadi sebelum kepailitan tadi harus dihentikan. Jadi secara otomatis apabila ada

Didin R Dinovan, Kewenangan Pengadilan Niaga Mengadili Perkara Kepailitan ..... 
putusan arbitrase, kemudian menurut ketentuan Pasal 61 UU No.30 Tahun 1999 pemenangnya atau pemilik hak memohon eksekusi ke Pengadilan Negeri dan Ketua Pengadilan Negeri mengeluarkan ketetapan eksekusi kemudian ada pailit, maka putusan ini demi hukum harus dihentikan oleh ketentuan Pasal 24 ayat (1) UUK.

Pada saat sesudah pernyataan pailit, apabila dalam sengketa perdata umum atas ketentuan Pasal 130 HIR, hakim wajib mengusahakan agar penggugat dan tergugat mengakhiri dengan perdamaian. Undang-Undang Kepailitan tidak mengatur hal itu, karena itu tidak ada kewajiban bagi hakim Pengadilan Niaga mengusahakan agar kreditor dan debitor mengakhiri perkara kepailitannya dengan perdamaian. Otomatis tidak ada penyelesaian melalui arbitrase pada saat proses perkara kepailitan sedang berlangsung. Hal ini karena ketentuan dalam Pasal 130 HIR tidak diterapkan pada Undang-Undang Kepailitan. Perdamaian hanya dapat dilaksanakan menurut ketentuan Pasal 144 UUK, dimana harus ada tawaran perdamaian antara debitor kepada semua kreditor. Jadi tidak bisa antara debitor pribadi dengan kreditor pribadi yang membuat perjanjian arbitrase. Kesimpulannya arbitrase tidak dapat dilaksanakan atau lembaga arbitrase tidak bisa berfungsi pada saat Pengadilan Niaga sudah memutus perkara permohonan pernyataan pailit.

Klausula arbitrase baru dapat memiliki kewenangan absolut untuk mementahkan hak memeriksa dan mengadili apabila berhadapan dengan kewenangan absolut Pengadilan Negeri. Kedudukan tersebut telah ditegaskan dalam Pasal 11 ayat (2) Undang-Undang No.30 tahun 1999 tentang arbitrase jo Pasal 3 Undang-Undang No.14 tahun 1970 jo jo Pasal 377 Herzien Inlandsch Reglement jo Pasal 615-651 Reglement op de Rechtsvordering. Bentuk perjanjian arbitrase dalam suatu kontrak dapat berupa :

\section{Pactum de Compromittendo}

Klausula ini dibuat sebelum terjadinya sengketa di antara para pihak, dan dipersiapkan untuk mengantisipasi sengketa atau perselisihan yang mungkin akan timbul di kemudian hari. Pembuat klausula pactum de compromittendo dapat berupa mencantumkan klausula arbitrase ke dalam perjanjian pokok dan dibuat dalam akta tersendiri, terpisah dari perjanjian pokoknya.

\section{Akta Kompromis}

Klausula arbitrase baru dibuat dan disepakati setelah terjadinya sengketa. Maka dari itu, pembuatan akta kompromis syaratnya dilakukan setelah terjadi sengketa, bentuknya harus tertulis, harus ditandatangani oleh para pihak dan dalam hal para pihak tidak dapat menandatangani, maka pembuatannya harus dilakukan di hadapan notaris. Karena arbitrase didasarkan pada suatu perjanjian, maka sebagai salah satu bentuk perjanjian, sah tidaknya perjanjian arbitrase digantungkan pada syarat-syarat sahnya suatu perjanjian, sebagaimana tercantum dalam Pasal 1320 KUH Perdata, yaitu kecakapan, kesepakatan, suatu hal tertentu, dalam perjanjian arbitrase yaitu sengketa dan sebab yang halal, dalam perjanjian arbitrase, yaitu sengketa di bidang hukum dagang.

Jika suatu perjanjian arbitrase telah memenuhi syarat-syarat sahnya suatu perjanjian menurut Pasal 1338 ayat (1) KUH.Perdata, perjanjian arbitrase tersebut berlaku sebagai undang-undang yang mengikat bagi para pihak pembuatnya. Pada dasarnya antara kalusula arbitrase atau clause compromissoire (pactum de

Didin R Dinovan, Kewenangan Pengadilan Niaga Mengadili Perkara Kepailitan ..... 
compromittendo) dan akta kompromis (acta compromis) tidak ada perbedaan yang signifikan, karena keduanya mempunyai akibat hukum, yaitu :

1) Sengketa yang akan timbul tidak akan diperiksa dan diputus oleh pengadilan, sehingga tidak perlu diselesaikan melalui prosedur beracara gugat menggugat dan banding, dan

2) Sengketa yang timbul akan diperiksa dan diputus oleh seorang arbiter atau para arbiter, dimana kedua belah pihak berkewajiban membantu pelaksanaan dan kelancaran arbitrase, serta mentaati putusan yang dikabulkan.

\section{PENUTUP}

\section{Kesimpulan}

Bertitik tolak dari permasalahan berdasarkan data yang didapat dari hasil penelitian dilapangan dan setelah dianalisa data tersebut, maka disimpulkan sebagai berikut :

1. Pengadilan Niaga mempunyai kompetensi absolut untuk memeriksa, mengadili dan memutus perkara kepailitan, meskipun dasar pengajuan pailit didasarkan pada perjanjian yang berklausula arbitrase dalam perjanjian yang disepakati para pihak sesuai dengan ketentuan Pasal 1 jo Pasal 280 ayat (1) Undang-Undang No. 4 Tahun 1998 yang diubah dengan Undang-Undang No. 37 tahun 2004 tentang Kepailita Dan Penundaan Kewajiban Pembayaran Utang terdapat pada Pasal 1 jo. Pasal 300.

2. Permohonan pengajuan pailit atas suatu perjanjian dengan klausula arbitrase yang dibuat sebelum maupun sesudah adanya sengketa, harus diterima secara langsung, tanpa harus terlebih dahulu ada proses penyelesaian melalui Lembaga Arbitrase, hal ini dipertegas dengan adanya ketentuan dalam Pasal 303 Undang-Undang No. 37 tahun 2004 Tentang Kepailitan dan Penunndaan Kewajiban Pembayaran Utang.

3. Upaya hukum terhadap adanya putusan pailit yang berklausula arbitrase oleh Pengadilan Niaga pada prinsipnya sama dengan perkara pada umumnya bersifat serta merta dapat dilaksanakan terlebih dahulu, upaya hukum yang dapat diajukan terhadap putusan atas permohonan pernyataan pailit adalah dengan mengajukan kasasi ke Mahkamah Agung R.I. dan Peninjauan Kembali (PK).

\section{B. Saran-saran.}

1. Pengadilan Niaga walaupun mempunyai kompetensi absolut terhadap perkara kepailitan, tetapi hendaknya tetap harus teliti dalam mencermati perkara permohonan kepailitan yang diajukan khususnya terhadap perkara permohonan kepailitan yang didalam perjanjiannya terdapat klusula arbitrase.

2. Adanya pandangan dan pendapat yang sama dari Hakim-Hakim Niaga baik pada tingkat Pengadilan Niaga maupun Mahkamah Agung R.I. dalam penanganan perkara kepailitan yang diajukan dengan dasar perjanjian berklausula arbitrase, khususnya ketika menetapkan putusan pailit, apalagi sudah ditentuan dalam Pasal 303 Undang-Undang No.37/2004 yang ditegaskan bahwa Pengadilan Niaga tetap

Didin R Dinovan, Kewenangan Pengadilan Niaga Mengadili Perkara Kepailitan ..... 
berwenang memeriksa dan menyelesaikan permohonan pernyataan pailit dari para pihak yang terikat perjanjian yang memuat klausula arbitrase.

3. Bagi para pihak yang membuat perjanjian utang piutang, hendaknya perumusan klausula arbitrase secara tegas dan pasti disebutkan kewenangan mengadilinya agar tidak dimanfaatkan oleh pihak yang beritikad tidak baik.

\section{DAFTAR PUSTAKA}

Cremes, 1975, Wetboek van Koophandel - Failissementswest, Editie Cremers.

Departemen Kehakiman dan Hak Asasi Manusia R.I. Direktur Jenderal Badan Peradilan Umum dan Peradilan Tata Usaha Negara, 2001, Himpunan Putusan-Putusan Pengadilan Niaga, Perkara Niaga, Jakarta.

Emmy Yuhassarie, 2004, Interaksi Antara Arbitrase dan Proses Kepailitan, Pusat Pengkajian Hukum, Jakarta.

Gunawan Widjaja, 2008, Arbitrase vs. Pengadilan Persoalan Kompetensi (Absolut) Yang Tidak Pernah Selesai, Penerbit Prenada Media Group, Jakarta.

Himpunan Putusan-Putusan Pengadilan Niaga Tahun 1999, Departemen Kehakiman dan Hak Asasi Manusia Republik Indonesia, Direjen Badan eradilan Umum dan Peradilan Tata Usaha Negara, Jakarta.

Himpunan Kajian Putusan Mahkamah Agung dan Pengadilan Niaga mengenai Perkara Permohonan Pernyataan Pailit, 2000, Proyek Pembinaan Tehnis Justisial MA, Jakarta.

Inservice Training, 2003, Beberapa Materi Kepailitan Pada Pelatihan Pusdiklat Mahkamah Agung RI, Penerbit Pusdiklat Mahkamah Agung RI,Jakarta.

Kartono, 1974, Kepailitan dan Pengunduran Pembayaran, Pradnya Paramita, Jakarta.

M Ali Boediarto, 2001, Kompilasi Abstrak Hukum Putusan Mahkamah Agung tentang Kepailitan, Ikatan Hakim Indonesia, Jakarta.

M Yahya Harahap, 1997, Beberapa Tinjauan Mengenai Sistem Peradilan dan Penyelesaian Sengketa, Citra Aditya Bakti, Bandung. 